\title{
Atahualpacoris henryi, a new species of plant bug from Colombia (Heteroptera, Miridae, Mirini)
}

\author{
Paulo Sérgio Fiuza Ferreira', Jose Luis Benavides Lopes², Fagner de Souza ${ }^{3}$, \\ Luciano Santana Fiuza Ferreira ${ }^{4}$
}

I Universidade Federal de Viçosa, Departamento de Entomologia, Viçosa, MG, Brazil 2 Muséum National d'Histoire Naturelle, Département Systématique et Evolution, Paris, France 3 Universidade Federal do Triângulo Mineiro, Laboratório de Ecologia Aquática, Avenida Guilherme Ferreira, 1940, Uberaba, Minas Gerais, Brazil 4 Universidade de Viçosa, Faculdade de Ciências Biológicas e da Saúde, Engenharia Ambiental. Av. Maria de Paula Santana, no 3815- Bairro Silvestre Viçosa, Minas Gerais, 36570-000, Brazil

Corresponding author: Paulo Sérgio Fiuza Ferreira (pfiuza@ufv.br)

Academic editor: A. Wheeler | Received 4 September 2017 | Accepted 18 October 2018 | Published 15 November 2018

http://zoobank.org/5ABFEDEF-91FA-4D68-B1F7-04FECFF575CD

Citation: Ferreira PSF, Lopes JLB, Souza F, Ferreira LSF (2018) Atahualpacoris henryi, a new species of plant bug from Colombia (Heteroptera, Miridae, Mirini). In: Wheeler Jr AG (Ed.) A Festschrift Recognizing Thomas J. Henry for a Lifetime of Contributions to Heteropteran Systematics. ZooKeys 796: 175-185. https://doi.org/10.3897/zookeys.796.20801

\begin{abstract}
A new species of plant bug in the genus Atahualpacoris Carvalho, tribe Mirini, is described. Morphological characters differentiating Atahualpacoris from the related genus Calocorisca are provided, and a diagnosis of each known species of Atahualpacoris is presented. Specimens of the new species were collected by light trap in a natural ecosystem of the Andes Mountains, Department of Tolima, Colombia. The adult and male genitalia are illustrated.
\end{abstract}

\section{Keywords}

Atahualpacoris, description, morphology, Neotropical Miridae

\section{Introduction}

Carvalho (1985) described Atahualpacoris in the subfamily Mirinae, tribe Mirini. Currently, the genus contains six species distributed in Andean America: A. columbiensis Carvalho, 1985 (Colombia and Peru), A. impunctatus Carvalho, 1985 (Venezuela),

Copyright P.S.F. Ferreira et al. This is an open access article distributed under the terms of the Creative Commons Attribution License (CC BY 4.0), which permits unrestricted use, distribution, and reproduction in any medium, provided the original author and source are credited. 
A. incaicus Carvalho, 1985 (Peru), A. lojaensis Carvalho, 1985 (Ecuador), A. tamboensis Carvalho, 1985 (Colombia, Ecuador and Peru), and A. venezuelensis Carvalho, 1985 (Venezuela) (Carvalho 1985, Schuh 2002-2013).

In this paper, a new species, Atahualpacoris henryi, is described. Illustrations of the adult and male genitalia and a key to species are provided to facilitate species recognition.

\section{Materials and methods}

Specimens were collected by light trap in the central cordillera of the Andes mountains, Cajamarca, at Tolima department of Colombia. The collection areas correspond to Veredas: Cristales La Paloma, Vereda La Luisa and include Montane Wet Forest and Very Humid Montano Low Forest, with elevations ranging from 2100 to 3200 meters above sea level. Rainfall exceeds $2000 \mathrm{~mm}$ /year, and temperatures are lower than $18^{\circ} \mathrm{C}$. The rugged topography is characterized by steep slopes (Holdridge 1967).

Ten traps were used to take 11 samples in two areas from May 2012 to March 2013. Traps (Luiz de Queiroz model) with a UV 15-watt fluorescent lamp were installed $2 \mathrm{~m}$ above ground (Ferreira and Martins 1982). Traps were activated one day a week from 1800-0700 hr and all specimens were collected after $0700 \mathrm{hr}$.

Male genitalia were prepared by immersing them in room temperature $\mathrm{KOH}$ for 24 hours until they were softened and cleared. After being rinsed in distilled water, genitalia were placed in an excavated microscopic slide containing glycerol, and the endosoma, right and left parameres, and phallotheca were dissected using a Leica M205 A stereoscope. Material was preserved in glycerin in a microvial that was the pinned below the specimen. Terminology for male genitalia follows Cassis (2008). Images of the adult male and male genitalia were captured using a Leica MC170 HD digital microscope camera.

The holotype and paratypes are deposited in the Regional Museum of Entomology of the Federal University of Viçosa, MG, Brazil (UFVB).

\section{Taxonomy}

\section{Atabualpacoris Carvalho}

Diagnosis. Medium to large size $(6-10 \mathrm{~mm})$, oval-elongate, covered with short, adpressed pubescence. Front striated and vertex grooved. Pronotum trapeziform, narrowed to head, strongly punctate with lateral margins rounded; calli smooth; collar shiny and well defined. Scutellum rough and punctate, shiny and swollen. Hemelytra smooth, covered with short, adpressed pubescence.

Remarks. Atahualpacoris and Calocorisca (Carvalho 1985, 1986) are morphologically similar genera. Atahualpacoris has the body elongate with the lateral margins parallel or nearly so, and the scutellum is convex and raised at the middle, with its apex acute, slightly curled upward. The hemelytral membrane length is longer than in 
Calocorisca (Atahualpacoris length of hemelytra 1.7 to 1.9 times length of membrane; Calocorisca length of hemelytra 2.2 to 2.5 times length of membrane). Antennal segment I is covered by short setae mixed with common hairs, whereas in Calocorisca this segment is covered by erect setae longer than the width of the segment.

\section{Key to the species of Atahualpacoris}

$1 \quad$ General color brown or dark brown to black......................................... 2

- General color light brown, yellowish brown or reddish brown ...................6

2 Collar of pronotum brown to dark brown; antenna uniformly brown or yellowish, or apex of segments II, III and IV, black; scutellum uniformly brown or dark brown with a pale longitudinal stripe or with yellowish spots. Male: endosoma with one or two spicules; longer spicule lacking many flat spines on ventral surface; area near secondary gonopore with spines, denticles or serrate edges; left paramere with sensorial lobe not crenulate. 3

- Collar yellowish; scutellum not uniformly brown, with two lateral irregular stripes and apex yellow; antennal segment I yellowish with a basal and lateral black spots; II to IV black with apex yellow. Male: endosoma with three spicules; area near secondary gonopore absent; left paramere C- shaped and twisted toward broad apex; sensorial lobe stout and weakly crenulate.

A. henrysp. n.

3 Clavus brown; hemelytron membrane darkened; scutellum dark brown without pale longitudinal stripe. Male: endosoma with one spicule; area near secondary gonopore with outer margin bearing long spine, smaller spines of different sizes and denticles, or with enlarged apical region with edge serrate, or broad area with dorsal margin formed by series of denticles and one acute

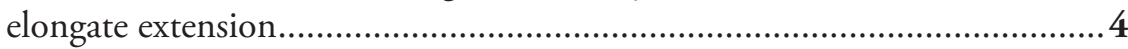
Clavus with longitudinal yellowish stripe following claval vein; hemelytron membrane pale with numerous small brown spots; scutellum dark brown with pale yellowish spots, apex and longitudinal median stripe pale. Male: endosoma with two spicules, a longer spicule curved, apex acute, a small spicule more robust, thickened to tip with apex curved and sharp; area near secondary gonopore with distal region denticulate; left paramere with welldeveloped sensorial lobe nearly $1 / 3$ of paramere length, apical region twisted, apex broad with lateral edges acute

A. columbiensis Carvalho

$4 \quad$ Scutellum and cuneus uniformly brown; hemelytron membrane with two light spots on outer margin, and veins pale. Male: endosoma with long, narrow and curved spicule tapered in apical 1/3, with apex acute; area near secondary gonopore with outer margin bearing long spine, smaller spines of different sizes, and denticles; left paramere with sensorial lobe bearing small tubercles, apex forked and twisted A. impunctatus Carvalho 
5 Antenna yellowish; scutellum dark brown with apex and scattered spots pale; cuneus with small pale spots; hemelytron membrane darkened with many small brown spots. Male: endosoma with long spicule, apical third tapered and curved; area near secondary gonopore with enlarged apical region with serrated edge; left paramere strongly curved; sensorial lobule well developed, very small denticles on surface

A. incaicus Carvalho

- $\quad$ Antenna brown; scutellum dark brown with small spots at apex yellowish; cuneus with small rounded yellowish spots; hemelytron membrane darkened with numerous small yellowish spots. Male: endosoma with long, broad spicule, apex tapering and curved; area near secondary gonopore broad, its dorsal margin formed by series of denticles and acute, elongate spinelike extension; left paramere sickle-shaped with apex blunt; sensorial lobe small, rounded, dorsal surface with many small denticles and long hairs

A. venezuelensis Carvalho

6 Antenna yellowish; pronotum yellowish with brown spots; collar black; scutellum dark brown with apex and small spots whitish; clavus and cuneus with small black spots along claval suture; hemelytron membrane darkened with scattered small brown spots, and large pale spot close to apex of cuneus; Male: endosoma with long stout spicule, apical 1/3 bent at right angle, extreme apex tapered and twisted; area near secondary gonopore absent; left paramere with sensorial lobe developed and flattened; apex strongly curved and blunt

A. jojaensis Carvalho Antennal segment I reddish with tiny sclerotized black dots; pronotum reddish with numerous small yellowish spots; collar reddish; scutellum with brown and yellowish spots; clavus reddish brown; cuneus with basal area dark; hemelytron membrane darkened with many small brown spots and red veins. Male: endosoma with long spicule, curved and tapering to apex; area near secondary gonopore with apical margin serrate; left paramere falciform, sensorial lobe strongly developed with long hairs, apex twisted and blunt .....

A. tamboensis Carvalho

\section{Atabualpacoris henryi sp. n.}

http://zoobank.org/D976195C-C98A-414F-A631-44087BAE7601

Figs $1-4$

Diagnosis. Distinguished from other species of Atahualpacoris by large size (8.0 to 9.5 $\mathrm{mm}$ ) with general color dark brown to black; hemelytra dark brown; two large yellowish spots on corium; cuneus with yellowish spots near cuneal fracture on inner basal angle and at apex; hemelytral membrane darkened with many small, rounded, scattered, pale spots; absence of black spot at base of larger cells of hemelytral membrane; male genitalia: endosoma with three spicules of different size and shape, acute distally; longer spicule with many flat spines on ventral surface; left paramere sickle shaped, apex broad and twisted, sensorial lobe crenulate. 


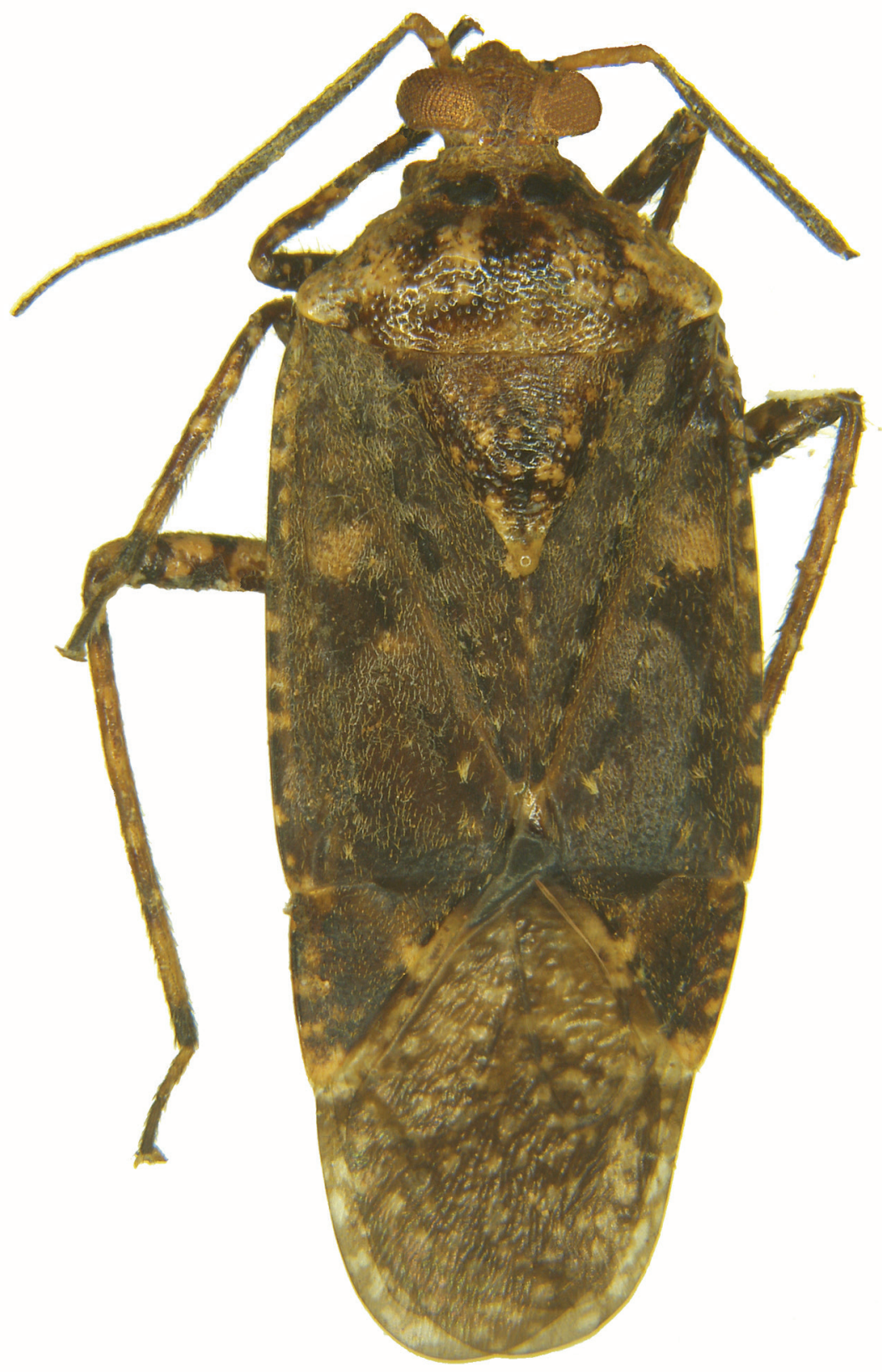

Figure I. Atahualpacoris henryi sp. n. male, holotype (dorsal view).

Holotype male (Figs 1-3); measurements (Table 1).

Description. Body shiny, parallel sided, length ca. 2.5 times width, dorsal vestiture with short, semi-erect hairs; general color dark brown to black with spots and small marks yellowish. Head declivous, shiny, broader than long, weakly convex dorsally; in 
Table I. Characters measurements in millimeters taken from Holotype first, followed by range (minimum and maximum) of five males and five females specimens, and average for each character.

\begin{tabular}{lccccccc}
\hline \multicolumn{1}{c}{ Caracteres } & Holotype & min & $\begin{array}{c}\text { Male } \\
\text { max }\end{array}$ & average & min & $\begin{array}{c}\text { Female } \\
\text { max }\end{array}$ & average \\
\hline Body length & & 7,60 & 9,00 & 8,60 & 8,40 & 10,00 & 9,44 \\
Body width & 3,5 & 3,10 & 3,70 & 3,40 & 3,40 & 3,80 & 3,60 \\
Head length & 0,7 & 0,50 & 0,70 & 0,62 & 0,50 & 0,70 & 0,60 \\
Head width & 1,4 & 1,30 & 1,40 & 1,32 & 1,30 & 1,40 & 1,34 \\
Head distance between eyes & 0,36 & 0,33 & 0,38 & 0,36 & 0,44 & 0,49 & 0,46 \\
Antennal segment I length & 0,90 & 0,79 & 0,90 & 0,85 & 0,79 & 0,87 & 0,84 \\
Antennal segment II length & 1,97 & 1,90 & 2,41 & 2,09 & 1,87 & 2,10 & 2,03 \\
Antennal segment III length & 0,79 & 0,79 & 0,92 & 0,86 & 0,82 & 0,92 & 0,88 \\
Antennal segment IV length & 0,59 & 0,59 & 0,69 & 0,65 & 0,62 & 0,67 & 0,64 \\
Pronotum length & 1,38 & 1,21 & 1,41 & 1,35 & 1,18 & 1,38 & 1,32 \\
Pronotum width at base & 3,05 & 2,72 & 3,08 & 2,95 & 3,03 & 3,25 & 3,16 \\
Hind femur length & 2,38 & 2,21 & 2,64 & 2,45 & 0,85 & 0,92 & 0,89 \\
Hind tibia length & 3,31 & 3,16 & 3,50 & 3,33 & 3,22 & 3,47 & 3,33 \\
Hind tarsus length & 0,90 & 0,79 & 0,92 & 0,88 & 0,85 & 0,92 & 0,89 \\
Scutellum length & 1,46 & 1,33 & 1,49 & 1,41 & 1,54 & 1,69 & 1,59 \\
Scutellum width & 1,54 & 1,36 & 1,62 & 1,49 & 1,59 & 1,69 & 1,64 \\
Hemelytron length & 7,27 & 6,45 & 7,60 & 7,16 & 6,94 & 8,43 & 7,95 \\
Cuneus length & 1,41 & 1,05 & 1,41 & 1,30 & 1,41 & 1,64 & 1,53 \\
Cuneus width & 1,33 & 1,18 & 1,46 & 1,35 & 1,26 & 1,49 & 1,41 \\
Rostrum length & 2,22 & 2,13 & 2,75 & 2,41 & 2,19 & 2,81 & 2,39 \\
\hline
\end{tabular}

dorsal view dark brown with yellowish stripes; frons with longitudinal median groove; eyes prominent, contiguous to collar, occupying most of head in dorsal view; vertex with transverse sulcus; antennal vestiture with short pilosity, less than width of segment; antennal fossa above jugal-loral suture dark brown; antennal segment I shorter than width of vertex between eyes, bearing short setae mixed with common hairs, yellowish with extreme base and lateral spots black; segments II-IV black, extreme apex yellow, with whitish adpressed pilosity; relative lengths of antennal segments in ascending order II $<$ I $<$ III $<$ IV; eyes black; rostrum brown with light brown spots, reaching mesosternum; lateral margins of clypeus, posterior area of juga and loral-jugal suture dark brown; epipharynx brown at base. Pronotum dark brown, trapeziform, two times wider than long, vestiture with sparse, short, pale hairs; collar yellowish; callus black, swollen, shiny, smooth with lateral sides slightly marginate; disc of pronotum convex, shiny, distinctly rugose and punctate with irregular yellowish spots; humeral angles slightly depressed; pronotum ventrally with xypho of prosternum yellowish with brown spots; propleura dark brown, shiny, rugose and punctate with sparse, adpressed hairs; mesosternum dark brown, slightly rugose and punctate; mesepisternum and metaepisternum dark brown; ostiolar peritreme brown with median lobe developed and evaporative area yellowish; coxae and femora with semierect hairs shorter than width of segment; coxae black with yellowish spots; posterior margins of median coxae yellowish; femora black with scattered yellowish spots; tibiae brown with scattered yellowish spots, parallel rows of tiny 


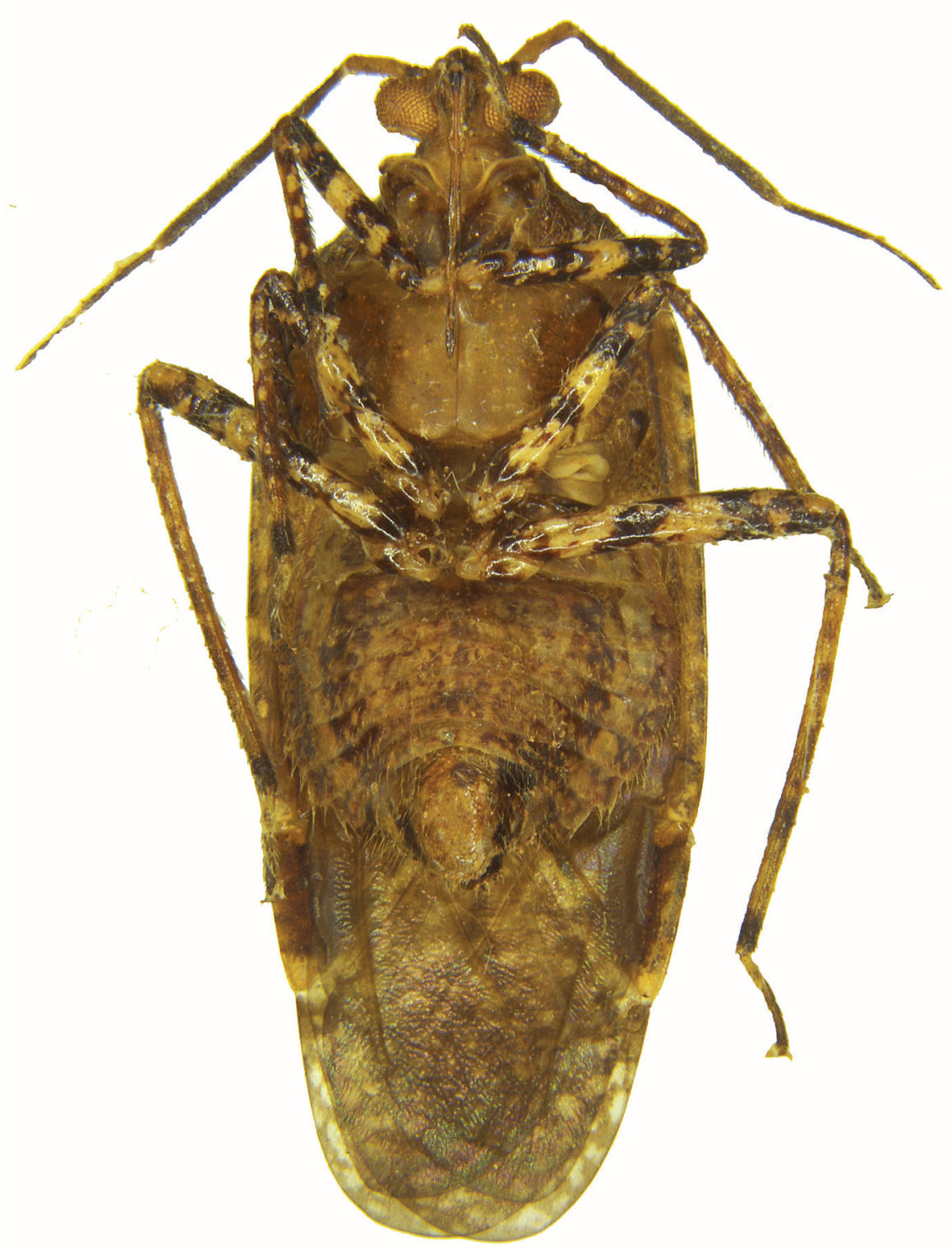

Figure 2. Atahualpacoris henryi sp. n. male, holotype (ventral view).

black spines along entire length, and vestiture of common semi-adpressed pale hairs mixed with dark bristles shorter or equal to width of segment; length of hind tibia more than 3.5 times length of hind tarsus; tarsi brown, darkening to apex. Scutellum triangular, rugose, shiny, slightly convex, and raised at middle, with apex acute, slightly curled upward; general color dark brown with two lateral irregular stripes, apex yellow; clothed with sparse semi-erect hairs. Hemelytron dark brown, elongate, subparallel, lateral mar- 


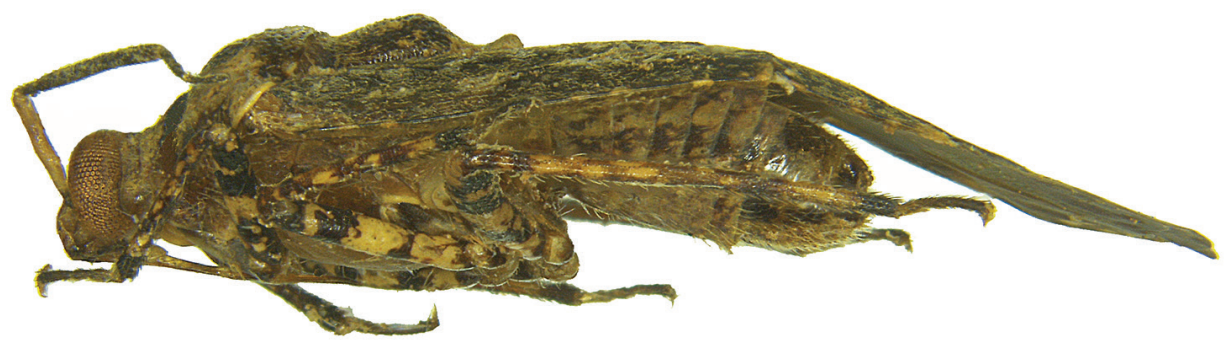

Figure 3. Atahualpacoris henryi sp. n. male, holotype (lateral view).
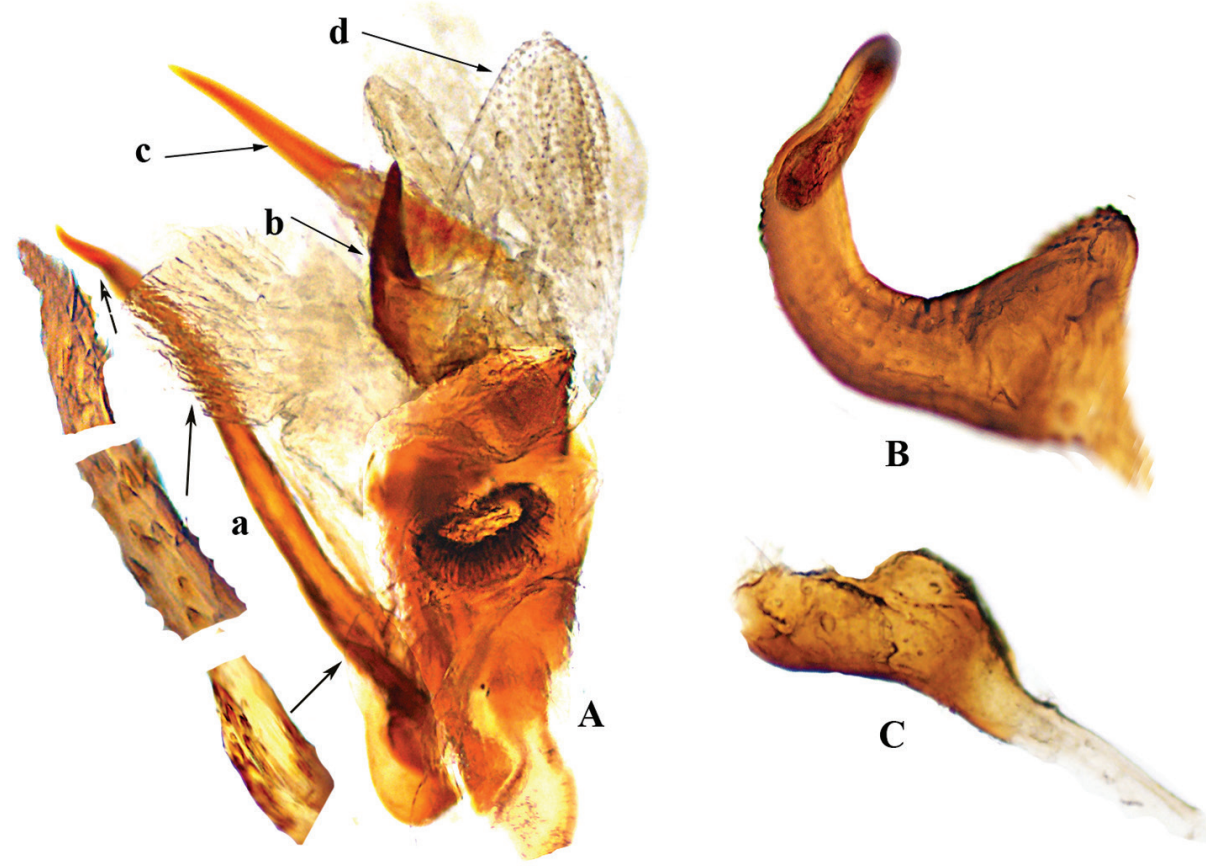

Figure 4. Atahualpacoris henryi sp. n. male, holotype $\mathbf{A}$ endosoma a longer spicule with many flat spines b shorter sickle-shaped spicule $\mathbf{c}$ third spicule larger at base $\mathbf{d}$ membranous lobes with tiny teeth $\mathbf{B}$ left paramere $\mathbf{C}$ right paramere.

gins slightly rugose with short, pale, adpressed pubescence mixed with dark hairs; clavus black; two large, somewhat rounded spots on corium, and small patches throughout embolium yellowish; claval-corial suture and embolio-corial suture impunctate; embolium delimited along entire length; cuneus slightly longer than wide with small spots 
Table 2. Results of Principal Component Analysis for Atahualpacoris henryi sp. n. (PCA). Bold values are the ones that most influence the divergences.

\begin{tabular}{lcc}
\hline & Jolliffe cut-off: $\mathbf{0 , 0 0 3}$ & \\
Eigenvalue & PCA1 & PCA2 \\
\% Variance & 0,073315 & 0,005824 \\
\hline Body length & 83,874 & 6,6633 \\
Body width & 0,003118 & 0,02205 \\
Head length & 0,03958 & 0,2028 \\
Head width & $\mathbf{0 , 1 1 1 8}$ & 0,1741 \\
Head distance between eyes & 0,07589 & 0,2386 \\
Antennal segment I & $\mathbf{0 , 1 1 7 6}$ & 0,3677 \\
Antennal segment II & $\mathbf{0 , 1 0 5 6}$ & 0,2467 \\
Antennal segment III & $\mathbf{0 , 1 1 1 1}$ & 0,1195 \\
Antennal segment IV & 0,06692 & 0,2308 \\
Pronotum length & $\mathbf{0 , 1 0 6 8}$ & 0,2588 \\
Pronotum width at base & $\mathbf{0 , 1 0 8 8}$ & 0,213 \\
Hind femur length & 0,0297 & 0,2007 \\
Hind tibia length & $\mathbf{0 , 9 4 0 8}$ & $-0,1782$ \\
Hind tarsus length & 0,08981 & 0,2269 \\
Scutellum length & 0,07514 & 0,1453 \\
Scutellum width & $-0,01467$ & 0,257 \\
Hemelytron length & 0,006607 & 0,2507 \\
Cuneus length & $-0,00684$ & 0,005071 \\
Cuneus width & $\mathbf{- 0 , 0 5 4 4 8}$ & 0,1889 \\
Rostrum length & 0,06587 & 0,4241 \\
\hline & 0,08813 & 0,07838 \\
\hline
\end{tabular}

on outer margin, broad spot near cuneal fracture, spot on inner basal angle and apex yellowish; hemelytral membrane opaque, glabrous and slightly rugose, darkened with many scattered, small, pale spots. Abdomen brown with yellowish areas, vestiture with adpressed or semi-erect hairs.

Male genitalia (Figure 4). Endosoma (Figure 4A) with membranous lobes covered with tiny teeth (Figure 4Ad), and three thick spicules of different size and shape, acute distally; longer process narrow, rising below secondary gonopore, ventral surface with many flat spines (Figure 4Aa); second process shorter, broad, sickle-shaped (Figure 4Ad); third process larger at base, narrowed to acute apex (Figure 4Ac); secondary gonopore large, distinct, with rim wide and ribbed. Left paramere (Figure 4B) C-shaped in dorsal aspect, twisted toward broad apex; sensorial lobe relatively stout and weakly crenulate. Right paramere (Figure 4C) reduced, sensorial lobe relatively stout.

Female. Similar to males in structure and vestiture. Measurements (Table 1).

Geographic distribution. Colombia (Tolima).

Host plant. Unknown.

Etymology. Named in honor of Dr. Thomas J. Henry (National Museum of Natural History, Washington D.C.) for his great contributions to the knowledge of Heteroptera, especially the family Miridae. 
Table 3. Comparison of morphometric characters (in percentage) used in the diagnosis of sexual dimorphism of Atahualpacoris henryi sp. $\mathrm{n}$. Only characters with greater percentage differences of the relations between the characters. Min. $=$ Minimum values. Max. $=$ Maximum values. DP $=$ standard deviation .

\begin{tabular}{|c|c|c|c|c|c|c|c|c|c|}
\hline \multirow{2}{*}{ CHARACTERS } & \multirow{2}{*}{$\begin{array}{c}\text { Holotype } \\
(\text { male })\end{array}$} & \multicolumn{4}{|c|}{ Male } & \multicolumn{4}{|c|}{ Female } \\
\hline & & Min. & Max. & Average & DP & Min. & Max. & Average & DP \\
\hline \multicolumn{10}{|c|}{ Body length } \\
\hline Hind femur length & 26,50 & 26,50 & 30,71 & 28,54 & 1,64 & 8,81 & 10,07 & 9,42 & 0,47 \\
\hline \multicolumn{10}{|c|}{ Body width } \\
\hline Hind femur length & 68,13 & 68,13 & 77,68 & 72,15 & 3,71 & 23,56 & 25,64 & 24,67 & 1,03 \\
\hline \multicolumn{10}{|c|}{ Head length } \\
\hline Hind femur length & 29,35 & 22,67 & 29,35 & 25,33 & 3,40 & 54,17 & 80,29 & 67,82 & 9,40 \\
\hline \multicolumn{10}{|c|}{ Head width } \\
\hline Head distance between eyes & 25,64 & 25,64 & 29,59 & 27,22 & 1,65 & 31,14 & 35,50 & 34,09 & 1,84 \\
\hline Hind femur length & 170,33 & 169,63 & 203,16 & 185,94 & 15,69 & 64,10 & 69,03 & 66,24 & 1,90 \\
\hline \multicolumn{10}{|c|}{ Head distance between eyes } \\
\hline Antennal segment I & 40,00 & 37,14 & 45,45 & 42,30 & 3,61 & 51,52 & 56,25 & 54,61 & 1,87 \\
\hline Hind femur length & 15,05 & 12,62 & 16,28 & 14,71 & 1,32 & 48,57 & 54,55 & 51,46 & 2,33 \\
\hline Hind tarsus length & 40,00 & 37,14 & 45,16 & 41,06 & 3,44 & 48,57 & 54,55 & 51,46 & 2,33 \\
\hline \multicolumn{10}{|c|}{ Hind femur length } \\
\hline Antennal segment I & 37,63 & 32,63 & 37,63 & 34,83 & 2,44 & 88,57 & 97,06 & 94,27 & 3,45 \\
\hline Antennal segment II & 120,78 & 107,45 & 127,16 & 117,78 & 7,18 & 41,46 & 45,21 & 43,83 & 1,42 \\
\hline Pronotum length & 172,22 & 172,22 & 194,34 & 181,86 & 9,49 & 62,96 & 76,09 & 67,56 & 5,31 \\
\hline Pronotum width at base & 78,15 & 78,15 & 88,79 & 82,97 & 3,94 & 27,35 & 28,43 & 28,05 & 0,44 \\
\hline Leg hind tibia length & 71,99 & 69,87 & 77,53 & 73,52 & 2,85 & 25,13 & 27,61 & 26,65 & 0,99 \\
\hline Leg hind tarsus length & 265,71 & 263,89 & 297,06 & 279,67 & 15,53 & 100,00 & 100,00 & 100,00 & 0,00 \\
\hline Scutellum length & 163,16 & 163,16 & 190,57 & 174,52 & 10,97 & 54,55 & 57,38 & 55,83 & 1,17 \\
\hline Scutellum width & 155,00 & 155,00 & 174,58 & 164,98 & 8,38 & 51,52 & 56,45 & 54,09 & 2,16 \\
\hline Hemelytron length & 32,79 & 32,04 & 37,60 & 34,29 & 2,15 & 10,66 & 12,19 & 11,19 & 0,59 \\
\hline Cuneal length & 169,09 & 169,09 & 209,76 & 189,43 & 16,30 & 53,13 & 63,64 & 58,01 & 3,90 \\
\hline Cuneal width & 178,85 & 177,19 & 186,96 & 181,23 & 4,06 & 56,90 & 71,43 & 63,51 & 6,40 \\
\hline Rostrum length & 107,48 & 91,70 & 115,77 & 102,58 & 9,85 & 31,00 & 39,89 & 37,35 & 3,60 \\
\hline \multicolumn{10}{|c|}{ Cuneal length } \\
\hline Antennal segment I & 63,64 & 59,62 & 78,05 & 65,99 & 7,66 & 51,56 & 56,36 & 54,58 & 1,87 \\
\hline Pronotum length & 98,18 & 98,18 & 114,63 & 104,14 & 6,78 & 83,64 & 88,52 & 85,93 & 2,24 \\
\hline Leg hind femur length & 169,09 & 169,09 & 209,76 & 189,43 & 16,30 & 53,13 & 63,64 & 58,01 & 3,90 \\
\hline Leg hind tibia length & 42,57 & 33,31 & 42,57 & 39,04 & 3,53 & 42,98 & 47,34 & 46,03 & 1,86 \\
\hline
\end{tabular}

Material examined. Holotype male, Colombia,Tolima, Cajamarca, La Colosa, C. Andina, Armadilha Luminosa, Febrero 2013, Benevides Lopes J.L. (ICN- Instituto de Ciencias Naturales, Universidad Nacional de Colombia, Bogotá) Paratypes: (Same locality of holotype): female, IX/2012; male, 4 females, XI/2012; 3 males, female, XII/2012; male, 2 females I/ 2013; 4 males, female II/ 2013 (UFVB- Universidade Federal de Viçosa, MG, Brazil). 


\section{References}

Carvalho JCM (1985) Mirídeos neotropicais, CCLVII: gênero Atahualpacoris n. gen. com descriçôes de seis espécies novas (Hemiptera). Revista Brasileira de Biologia 45: 547-556.

Carvalho JCM (1986) Mirídeos neotropicais, CCLXI: gênero Calocorisca Distant com descriçōes de espécies novas (Hemiptera). Revista Brasileira de Biologia 46: 55-77.

Cassis G (2008) The Lattinova complex of austromirine plant bugs (Hemiptera: Heteroptera: Miridae: Orthotylinae). Proceedings of the Entomological Society of Washington 110: 845-939. https://doi.org/10.4289/0013-8797-110.4.845

Ferreira PSF, Martins DS (1982) Contribuiçẫo ao método de captura de insetos por meio de armadilha luminosa, para obtenção de exemplares sem danos morfológicos. Revista Ceres, Viçosa 29: 538-543.

Holdridge LS (1967) Ecología basada en zonas de vida. Editorial IICA, San José, 206 pp.

Schuh RT (2002-2013) On-line Systematic Catalog of Plant Bugs (Insecta: Heteroptera: Miridae). http://research.amnh.org/pbi/catalog/ 